\title{
The effect of planting density and weed interference on agricultural traits of different rapeseed genotypes in Darab Region using multivariate statistical methods
}

\author{
Ali Rastegar ${ }^{1}$, Mahdi Zare ${ }^{1 *}$, Shahram SHARAFZADEH ${ }^{1}$, Korosh ORDOOKHANI ${ }^{1}$, Omid ALIZADEH² \\ ${ }^{1}$ Department of Agriculture, Firoozabad Branch, Islamic Azad University, Firoozabad, Iran. \\ ${ }^{2}$ Department of Agriculture, Shiraz Branch, Islamic Azad University, Shiraz, Iran. \\ *E-mail: maza572002@yahoo.com
}

Recebido em dezembro/2017; Aceito em abril/2018.

\begin{abstract}
RESUMO: Este estudo foi realizado com o objetivo de avaliar o efeito da densidade de plantio e da interferência de plantas daninhas em características agronômicas de diferentes genótipos de colza na região de Darab, utilizando métodos de análise multivariada. Para avaliar os componentes fisiológicos, morfológicos, produtivos e produtivos de genótipos de colza, realizou-se um experimento em parcelas subdivididas com delineamento de blocos casualizados, com três repetições na Província de Fars (estado de Darab, distrito de Forg), durante dois anos (2015-2017). Os tratamentos na parcela principal foram as densidades de plantas (densidades de 20, 40 e 60 plantas. $\mathrm{m}^{-2}$ ) e nas subparcelas a realização de capina completa, não capina e capina na fase de roseta. Além disso, as sub-parcelas incluíram as cultivares (Hayola 401, Sarigol e RGS003). Empregou-se o software SAS para análise da anova simples e composta, regressões e correlações, enquanto que, na análise dos componentes principais (ACP) foi usado o software minitab16 e os gráficos foram elaborado no software Excel. As médias também foram comparadas usando o teste de múltiplas frequências de Duncan (DMRT) a um nível de confiança de 5\%. Os resultados da análise da variância de caracteres mensurados mostraram que densidade, capina, cultivar, interação de densidade $\times$ capina, capina $\times$ cultivar $\mathrm{e}$ densidade $\times$ capina $x$ cultivar e interação de densidade $\times$ capina $\times$ cultivar e interação de densidade $\times$ cultivar foram significativos em ambos os anos (safras), inclusive na análise composta de dois anos a $1 \%$ de probabilidade. Os resultados deste experimento mostraram que a densidade de 20 plantas. $\mathrm{m}^{-2}$ aumentou a área foliar, número de ramos laterais, altura de planta, diâmetro de caule, número de vagens no caule principal, comprimento de vagem, distância da primeira vagem ao solo, peso de vagem fresca, número de sementes por vagem, peso de 1000 sementes, produção de sementes e de óleos em comparação com densidade de 60 plantas. $\mathrm{m}^{-2}$. Na análise do efeito da capina observou-se que a capina completa e a não capina, têm os valores numéricos máximo e mínimo para as mesmas variáveis supracitadas. A comparação da média do efeito da cultivar na área foliar, altura da planta e distância da primeira vagem ao solo mostrou que Sarigol teve a área foliar máxima em comparação à Hayola 401. Os resultados mostraram que a cultivar Hyola 401 teve maior rendimento que outras cultivares.
\end{abstract}

Palavras-chave: colza, características morfológicas, densidade de plantas, plantas daninhas, cultivares.

Efeito da densidade de plantio e da interferência de plantas daninhas em características agrícolas de diferentes genótipos de colza na região de Darab usando métodos estatísticos multivariados

\begin{abstract}
This study was carried out to evaluate the effect of planting density and weed interference on agronomic traits of different rapeseed genotypes in Darab region using multivariate analysis methods. To evaluate the physiological, morphological, yield and yield components of rapeseed genotypes, a split plot experiment was carried out based on a randomized complete block design with three replications in Fars province (Darab County, Forg District) during 2015-2017 (for two years). The treatments included main plot of plant density (densities of 20,40, and 60 plants per $\mathrm{m} 2$ ) and sub plot included complete weeding, non-weeding and weeding at the rosette stage. Moreover, sub plots included cultivars (Hayola 401, Sarigol, and RGS003). Simple and compound ANOVA, stepwise regression, and correlation were calculated using SAS software, and main components were analyzed using minitab16 software and charts were drawn using Excel software. Means were also compared using the Duncan's multiple range test (DMRT) at a confidence level of 5\%. The results of the analysis of the variance of measured traits showed that density, weeding, cultivar, interaction of density $\times$ weeding, weeding $\times$ cultivar, and density $\times$ weeding $\times$ cultivar and interaction of density $\times$ weeding $\times$ cultivar and interaction of density $\times$ cultivar were significant in both crop years and in compound analysis of two years at $1 \%$ probability level. The results of this experiment showed that density of 20 increased leaf area, number of lateral branches, plant height, stem diameter, number of pods of main stem, pod length, distance from first pod to ground, fresh pod weight, number of seeds per pod, weight of 1000 seeds, and seed and oil yields as compared with density of 60 . Comparison of mean of weeding effect on leaf area, plant height, number of main stem pods, distance from first branch to ground, stem diameter, pod length, distance from the first pod to
\end{abstract}


ground, fresh pod weight, weight of 1000 seeds, seed and oil yield showed that complete weeding and nonweeding have the maximum and minimum numerical values, respectively. Comparison of mean of cultivar effect on leaf area, plant height, and distance from first pod to ground showed that Sarigol had the maximum leaf area as compared with Hayola 401. Also, the results showed that Hyola 401 cultivar had more yield than other cultivars.

Keywords: rapeseed, morphological, density, weed, cultivar.

\section{INTRODUCTION}

Oil is one of the main foods that human consumes. About $20 \%$ of the daily human calorie requirement is provided by the oil depending on the different diets. Human essential oils are supplied from two animal and herbal sources. In the past, animal oils were used more to provide oil requirement. In Iran, too much of the consuming oil was provided from animal sources in the near past and vegetable oils were used in very low amounts and most of the vegetable oils were used in industrial and fuel applications. The required animal oil was also supplied from domestic sources and there was not much obligation for oil imports. With the increase in oil consumption, oil imports have begun since 1967. The growing trend of oil consumption led to the import of 512 thousand tons of oil in 1987 in order to meet the domestic demand. This trend continued to increase so that in 1998, the amount of the domestic consumption of oil reached about 850 thousand tons per year, of which only 61,000 tons were produced inside the country and the rest were imported (ZEINALI, 1999).

Therefore, due to the increasing population and consumption of oil in the country, it is necessary to increase oil production in the country. An increase in its prices will put pressure on the importing and consuming countries such as Iran. Therefore, regarding increasing population and consumption of oil in Iran per capita, it is necessary to increase the level of oilseed cultivation and increase their yield to reduce economic dependency on other countries. In the synthesis stage, herbal sugars are the origin of oil and these sugars are provided by the leaves to the organs that contain oil or fat such as seeds (whole oilseeds), fruits (coconut and oil palm), embryos (corn) and Rhizome (a species of lily) and subsequently they are synthesized of stored proteins. In the plasma of the cell, oil exists in the form of very fine droplets and into the emulsion state, which, by increasing concentration, can be seen as dispersed droplets. The formation of oil and fat belongs to the controlling genes in the first place and is subjected to environmental factors in the second place (ALIARI; SHEKARI, 2000).

Rapeseed (Brassica napus L.) is an oilseed plant that has been cultivated in our country today, and more than $90 \%$ of the country's oil is supplied through this plant (REZAEI; MALAKOOTI, 2000). Considering the development of the cultivated area of rapeseed in Iran, it is necessary to determine new cultivars that are suitable for climatic and soil conditions in each region, and appropriate crop tests that are suitable for climatic and soil conditions perform especially in the area of plant nutrition in each region (MIRZA SHAHI; SALIMPOUR, 2003). Proper plant density per unit area is also an important factor in the production of crops such as rapeseed. Scientists have found that high yields are due to factors such as proper and timely use of appropriate fertilizers, use of new cultivars, etc. when the plant density per unit area is appropriate and optimal (SADEGHI, 2000).
Rapeseed is a plant with good branching power and in low densities, it can compensate the low number of plants per unit area by increasing the number of branches to some extent. But in order to reach the potential seed yield, a desirable level of plant density is needed. Structural and vegetation characteristics are related to radiation absorption and play a decisive role in plant yield. The energy absorption of radiation on the surface of a product is desirable when leaf area is sufficient and is distributed uniformly so that it fully covers the surface of the earth. In order to achieve this objective, plant density should be changed and plant must be arranged properly on the soil surface.

Also, when plant population increases, the intensity of light in the coating is reduced and this decreases the number of sub branches and biomass of the plant. Increasing the plant population leads to an increase in the amount of accumulation of dry weight of the aerial organs per unit area and seed yield is increased then which is the result of an increase in leaf area index and better absorption of solar radiation and increased growth rate of the product (PURCELL et al., 2002). Selection of optimum plant density in autumn rapeseed and taking climatic conditions and soil of the region into consideration cause the plant to make complete use of all environmental factors such as water, air, light, and soil (SHIRANIRAD, 2002). Zimdahl (1980) stated in a study on crops that most crops tolerated the weeds a few weeks after the emergence of the seedlings, without any significant reduction in the amount of the product. Longer competition of weeds after germination of crop intensifies its effects, but in some cases, no particular effect is observed until the start of the competition; that is, when environmental resources such as water and nutrients become problematic for the plant (AIENEHBAND, 2006).

From the viewpoint of agricultural experts, several indicators have been presented to assess the progress of agriculture. However, the amount of attention paid to weed management is the factor that has recently been used as an appropriate index for assessing agricultural management in each country (or even in each field) (GUPTA, 2006). Sinapis arvensis, Chenopodium album, Nigella sativa, and Elymus have been introduced as the most important weeds in rapeseed fields. Seeds of rapeseed are mixed with the seeds of Brassicaceae weeds such as Sinapis arvensis, and it is difficult and even impossible to isolate them (SHARIATI; GHAZI SHAHNIZADEH, 2000). Total biomass produced in plant mixtures is constant to some extent. The presence of weeds in the field manifests its competition with crops and the reduction of dry matter and its yield. This competition is closely related to the life cycle of the crop and its maximum effect emerges in the early stages of crop growth so that the emergence of weeds after one third of the life cycle of a crop does not have a significant effect on yield loss (KOOCHAKI et al., 1997).

According to the mentioned contents and the importance and position of rapeseed, this study was conducted to 
investigate the effect of planting density and weed interference on the agronomic traits of different rapeseed genotypes in Darab region.

\section{MATERIALS AND METHODS}

\subsection{Geographical description of testing location}

This experiment was carried out as a field study in Darab County, Forg District, which is located 890 meters above sea level during 2015-2017. The average annual precipitation of this county is $235 \mathrm{~mm}$. Based on the data of a climatological station, average precipitation in Darab County is $264 \mathrm{~mm}$ for a period of 22 years. The average annual temperature of this city is $22.1^{\circ} \mathrm{C}$.

\subsection{Herbal material and the manner of performing experiment}

In order to evaluate the physiological, morphological, yield and yield components of rapeseed genotype, a split plot experiment was conducted in a randomized complete block design with three replications in Fars province (Darab County, Forg District) during 2015-2017 (two crop years). The examined treatments included main plot of plant density including densities of 20, 40, and 60 plants per $\mathrm{m} 2$ and sub plot included complete weeding, non-weeding and weeding at the rosette stage. Moreover, sub plots included cultivars (Hayola 401, Sarigol, and RGS003).

Each sub-plot consisted of 4 sowing lines with the distance of 0.45 meters and length of 3 meters. The distance between each two sub plots was 1 meter. Cultivation was carried out in rows, and the space between each two rows was $50 \mathrm{~cm}$. At the end of the season, one square meter of each plot was harvested after removal of the marginal effect for determining the final yield, and traits such as plant weight and its components, yield and its components (number of pods per unit area, number of seeds per pod and weight of 1000 seeds) and yield and seed oil percentage of the sample were measured. Pest and disease fighting was also done according to technical recommendations during the growth period.

\subsection{Trait measurement}

At the end of the season, one square meter of each plot was harvested after removal of the marginal effect for determining the final yield, and traits such as plant weight and its components, yield and its components (number of pods per unit area, number of seeds per pod and weight of 1000 seeds) and yield and seed oil percentage of the sample were measured.

Leaf area $\left(\mathrm{mm}^{2}\right)$, number of lateral branches, plant height $(\mathrm{cm})$, distance of first branch to ground $(\mathrm{cm})$, stem diameter $(\mathrm{mm})$, number of pods of main stem, length of pod $(\mathrm{mm})$, distance from first pod to ground $(\mathrm{cm})$, fresh pod weight $(\mathrm{g})$, dry pod weight (g), number of seeds per pod, weight of 1000 seeds $(\mathrm{g})$, stem weight $(\mathrm{g})$ manifest oil percentage and yield. Moreover, harvest operations were carried out after complete examinations. Leaf area was measured using a leaf area meter (Delta T Area Meter model) through photometric method. Plant height, distance of first branch to ground, distance of first pod to ground, and length of pod were measured using a millimeter ruler. The diameter of the stem was also measured using caliper. Number of lateral branches, number of main stem pods, and number of seeds per pod were counted carefully per plant. Fresh pod weight, dry pod weight, and stem weight were measured using a digital scale with accuracy of 0.001 . The oil of seeds was extracted using a Soxhlet extractor and methanol-chloroform organic solvent with a ratio of 1 to 2 in three replicates. This method has been employed by Joshi et al. (1998) for rapeseed, and Pritchard et al. (2000) also used this method for different rapeseed cultivars. This method is one of the most common methods for extracting fat, wax, and colorants from plant components (DASTPAK, 2001). In this method, the primary substance is placed in the presence of an organic solvent, for example, in the case of fat after a certain period, all of the fat that exist in the sample is dissolved in the solvent and is weighted after the evaporation of solvent.

\subsection{Statistical analysis}

This experiment was conducted during two years as split plot based on randomized complete block design with three replications. Simple and compound analysis of variance, stepwise regression, and correlation were calculated using SAS software and main components were analyzed using minitab16 software and charts were drawn using Excel software. Means were also compared using the Duncan's multiple range test (DMRT) at a confidence level of 5\%.

\section{RESULTS AND DISCUSSION}

\subsection{Leaf area}

The results of combined analysis of measured traits showed that density, weeding, cultivar, interaction of density $\times$ weeding, weeding $\times$ cultivar, and density $\times$ weed $\times$ cultivar were significant at $1 \%$ probability level, but the interaction of density $\times$ cultivar was not significant (Tables 1 and 2 ). The results of this experiment showed that density of 20 increased leaf area with means of $\left(90.48\right.$ and $90.87 \mathrm{~mm}^{2}$ in first and second years, respectively), as compared with density of 60 with means of $\left(84.44\right.$ and $84.54 \mathrm{~mm}^{2}$ in first and second years, respectively) (Table 3). Comparison of mean of weeding effect on leaf area showed that complete weeding with means of $\left(91.33\right.$ and $91.39 \mathrm{~mm}^{2}$ in first and second years, respectively) and non-weeding with means of (81.56 and $81.85 \mathrm{~mm}^{2}$ in the first and second years, respectively) have the maximum and minimum numerical values, respectively (Table 5). Comparison of mean of cultivar effect on leaf area showed that Sarigol cultivar had the maximum leaf area with means of (93.59 and $94.6 \mathrm{~mm}^{2}$ in first and second years, respectively), as compared with Hayola 401 with means of $\left(82.33\right.$ and $82.48 \mathrm{~mm}^{2}$ in the first and second years, respectively) (Table 7 ).

The experiments of evaluating the competitiveness of weeds with crops can provide important information on applying management practices. Fertilization management is one of the important components of the weed management system (Libeman and Mohler, 2001). Many weed species are superior to crops in absorbing added nutrients as fertilizers (BLACKSHOW et al., 2003), as sometimes they increase the growth of weed and result in its competition with crop and ultimately reduce crop yields. On the other hand, in some situations, crop can be more effective in absorbing fertilizers than weed (DHIMA; ELEFTHEROHORINOS, 2005).

Weeds compete with crops for resources and prevent proper crop access to resources, and thereby they reduce production and increase costs. In addition, the presence of weeds in rapeseed fields causes an increase in production cost resulting from control, reduction in the quality of 
product, and increase in the winnowing cost. On the other hand, since the most important broadleaf weeds belongs to Brassicaceae family, their chemical control in rapeseed, which itself belongs to this family, is difficult and sometimes impossible with existing herbicides (MOSAVI, 2008). Therefore, rapeseed cultivars which are tolerant to herbicide have been considered for better weed control. On the other hand, due to the adverse effects of these cultivars on agro ecosystems, their popularity has gradually diminished (POWLES et al., 1997). To reduce reliance on herbicides, alternative non-chemical control methods such as competition for crop production (BLACKSHOW et al., 1994) are required.

Table 1. Results of compound analysis of measured traits. (Average of squares)

\begin{tabular}{|c|c|c|c|c|c|c|c|c|c|}
\hline Change sources & DF & $\begin{array}{l}\text { Leaf } \\
\text { area }\end{array}$ & NLB & $\begin{array}{l}\text { Plant } \\
\text { height }\end{array}$ & DFFBG & $\begin{array}{c}\text { Stem } \\
\text { diameter }\end{array}$ & $\begin{array}{l}\text { Number of } \\
\text { main stem } \\
\text { pods }\end{array}$ & $\begin{array}{l}\text { Pod } \\
\text { length }\end{array}$ & DFFPG \\
\hline Year & 1 & $9.39 \mathrm{~ns}$ & $0.40 \mathrm{~ns}$ & $154.10^{* *}$ & $10.39 \mathrm{~ns}$ & $548.17 * *$ & $656.02 * *$ & $184.75^{* *}$ & $239.56^{* *}$ \\
\hline Density (a) & 2 & $542.00 * *$ & $5.27 * *$ & $389.80 * *$ & $35.28 * *$ & $1256.02 * *$ & $111430.78 * *$ & $133.43^{* *}$ & $216.22 * *$ \\
\hline Year $\times$ density & 2 & $1.19 \mathrm{~ns}$ & $0.04 \mathrm{~ns}$ & $3.41 \mathrm{~ns}$ & $0.38 \mathrm{~ns}$ & $2.49 \mathrm{~ns}$ & $36.01 \mathrm{~ns}$ & $12.54 \mathrm{~ns}$ & $3.14 \mathrm{~ns}$ \\
\hline Error in a & 8 & 3.74 & 0.10 & 18.45 & 1.85 & 13.50 & 16.07 & 11.90 & 7.79 \\
\hline Year $\times$ weeding & 2 & $1.46 \mathrm{~ns}$ & $0.04 \mathrm{~ns}$ & $11.43 \mathrm{~ns}$ & $0.82 \mathrm{~ns}$ & $16.71 \mathrm{~ns}$ & $27.90 \mathrm{~ns}$ & $0.04 \mathrm{~ns}$ & $3.75 \mathrm{~ns}$ \\
\hline Density $\times$ weeding & 4 & $22.60 * *$ & $0.51 * *$ & $69.84 \mathrm{~ns}$ & $2.84 \mathrm{~ns}$ & $59.02 * *$ & $526.98 * *$ & $6.02 \mathrm{~ns}$ & $37.06 * *$ \\
\hline Year $\times$ density $\times$ weeding & 4 & $4.01 \mathrm{~ns}$ & $0.14 \mathrm{~ns}$ & $3.83 \mathrm{~ns}$ & $1.04 \mathrm{~ns}$ & $6.80 \mathrm{~ns}$ & $71.35 * *$ & $1.40 \mathrm{~ns}$ & $2.88 \mathrm{~ns}$ \\
\hline Error in $b$ & 24 & 3.99 & 0.19 & 7.38 & 3.03 & 9.70 & 15.68 & 6.18 & 8.09 \\
\hline Cultivar (c) & 2 & $1870.80 * *$ & $77.52 * *$ & $26426.00 * *$ & $22530.05 * *$ & $11068.69^{* *}$ & $1923.56^{* *}$ & $269.65^{* *}$ & $33678.69 * *$ \\
\hline Year $\times$ cultivar & 2 & $2.02 \mathrm{~ns}$ & $0.30 \mathrm{~ns}$ & $4.02 \mathrm{~ns}$ & $0.58 \mathrm{~ns}$ & $4.19 \mathrm{~ns}$ & $11.19 \mathrm{~ns}$ & $1.80 \mathrm{~ns}$ & $6.34 \mathrm{~ns}$ \\
\hline Density $\times$ cultivar & 4 & $3.30 \mathrm{~ns}$ & $2.48 * *$ & $7.94 \mathrm{~ns}$ & $24.60 * *$ & $12.98 \mathrm{~ns}$ & $578.18 * *$ & $8.40 \mathrm{~ns}$ & $25.24 * *$ \\
\hline Year $\times$ density $\times$ cultivar & 4 & $0.81 \mathrm{~ns}$ & $0.03 \mathrm{~ns}$ & $6.59 \mathrm{~ns}$ & $0.27 \mathrm{~ns}$ & $5.01 \mathrm{~ns}$ & $19.31 \mathrm{~ns}$ & $9.07 \mathrm{~ns}$ & $2.91 \mathrm{~ns}$ \\
\hline Year $\times$ weeding $\times$ cultivar & 4 & $0.81 \mathrm{~ns}$ & $0.12 \mathrm{~ns}$ & $3.33 \mathrm{~ns}$ & $0.58 \mathrm{~ns}$ & $3.84 \mathrm{~ns}$ & $8.09 \mathrm{~ns}$ & $13.85^{*}$ & $6.69 \mathrm{~ns}$ \\
\hline Density $\times$ weeding $\times$ cultivar & 8 & $34.61 * *$ & $0.47 * *$ & $35.20 * *$ & $2.09 \mathrm{~ns}$ & $11.25 \mathrm{~ns}$ & $329.17 * *$ & $9.83 *$ & $18.03 *$ \\
\hline $\begin{array}{l}\text { Year } \times \text { density } \times \text { weeding } \times \\
\text { cultivar }\end{array}$ & 8 & $1.40 \mathrm{~ns}$ & $0.04 \mathrm{~ns}$ & $3.81 \mathrm{~ns}$ & $0.73 \mathrm{~ns}$ & $3.89 \mathrm{~ns}$ & $16.47 \mathrm{~ns}$ & $4.67 \mathrm{~ns}$ & $2.86 \mathrm{~ns}$ \\
\hline Error in $(\mathrm{c})$ & 72 & 2.49 & 0.12 & 7.51 & 2.88 & 8.16 & 18.39 & 4.75 & 7.91 \\
\hline
\end{tabular}

DF: degrees of freedom; NLB: number of lateral branches; DFFBG: distance from first branch to ground; DFFPG: distance from first pod to ground ns means non-significant; ${ }^{*}$ and ${ }^{* *}$ are significant at the probability level of $5 \%$ and $1 \%$, respectively.

Table 1. Continued. (Average of squares)

\begin{tabular}{|c|c|c|c|c|c|c|c|c|}
\hline Change sources & DF & $\begin{array}{c}\text { Fresh pod } \\
\text { weight }\end{array}$ & $\begin{array}{l}\text { Dry pod } \\
\text { weight }\end{array}$ & $\begin{array}{l}\text { Number } \\
\text { of seeds } \\
\text { per pod }\end{array}$ & $\begin{array}{l}\text { Weight } \\
\text { of } 1000 \\
\text { seeds }\end{array}$ & Yield per hectare & Oil yield & $\begin{array}{c}\text { Oil } \\
\text { percentage }\end{array}$ \\
\hline Year & 1 & $0.0417 * *$ & $0.222 * *$ & $338.00 * *$ & $0.05 \mathrm{~ns}$ & $32373814877 \mathrm{~ns}$ & $7039.97 \mathrm{~ns}$ & $7.79 \mathrm{~ns}$ \\
\hline Replication $\times$ Year & 4 & 0.0362 & 0.007 & 12.15 & 0.23 & 96223665247 & 17332.37 & 15.01 \\
\hline Density (a) & 2 & $0.0425 * *$ & $0.005 \mathrm{~ns}$ & $157.24 * *$ & $0.64 * *$ & $3136960000000 * *$ & $606738.35 * *$ & $134.97 * *$ \\
\hline Year $\times$ density & 2 & $0.0017 \mathrm{~ns}$ & $0.002 \mathrm{~ns}$ & $3.13 \mathrm{~ns}$ & $0.00 \mathrm{~ns}$ & $30961225988 \mathrm{~ns}$ & $7323.81 \mathrm{~ns}$ & $12.35 \mathrm{~ns}$ \\
\hline Error in a & 8 & 0.0017 & 0.001 & 4.31 & 0.07 & 24332688395 & 3507.67 & 32.32 \\
\hline Weeding (b) & 2 & $0.0365 * *$ & $0.013^{*}$ & $257.06 * *$ & $1.80 * *$ & $35056890000000 * *$ & $7518776.84 * *$ & $1687.08 * *$ \\
\hline Year $\times$ weeding & 2 & $0.0032 \mathrm{~ns}$ & $0.001 \mathrm{~ns}$ & $2.02 \mathrm{~ns}$ & $0.01 \mathrm{~ns}$ & $13902775988 \mathrm{~ns}$ & $3318.16 \mathrm{~ns}$ & $4.50 \mathrm{~ns}$ \\
\hline Density $\times$ weeding & 4 & $0.0096 * *$ & $0.002 \mathrm{~ns}$ & $1.24 \mathrm{~ns}$ & $0.02 \mathrm{~ns}$ & $496804064877 * *$ & $72299.98 * *$ & $24.79 \mathrm{~ns}$ \\
\hline Year $\times$ density $\times$ weeding & 4 & $0.0007 \mathrm{~ns}$ & $0.002 \mathrm{~ns}$ & $2.43 \mathrm{~ns}$ & $0.02 \mathrm{~ns}$ & $12303792654 \mathrm{~ns}$ & $2711.16 \mathrm{~ns}$ & $3.66 \mathrm{~ns}$ \\
\hline Error in $b$ & 24 & 0.0026 & 0.002 & 1.38 & 0.05 & 15731382531 & 3888.51 & 65.50 \\
\hline Cultivar (c) & 2 & $0.3323 * *$ & $0.059 * *$ & $17.91 * *$ & $5.37 * *$ & $7627151400000 * *$ & $1700884.22 * *$ & $340.78 * *$ \\
\hline Year $\times$ cultivar & 2 & $0.0004 \mathrm{~ns}$ & $0.002 \mathrm{~ns}$ & $0.91 \mathrm{~ns}$ & $0.01 \mathrm{~ns}$ & $8121091173 \mathrm{~ns}$ & $2017.69 \mathrm{~ns}$ & $2.44 \mathrm{~ns}$ \\
\hline Density $\times$ cultivar & 4 & $0.0395 * *$ & $0.016 * *$ & $2.56 \mathrm{~ns}$ & $0.15 * *$ & $494067589321 * *$ & $104486.44 * *$ & $29.92 \mathrm{~ns}$ \\
\hline Year $\times$ density $\times$ cultivar & 4 & $0.0004 \mathrm{~ns}$ & $0.001 \mathrm{~ns}$ & $1.84 \mathrm{~ns}$ & $0.09 * *$ & 19508502284 ns & $4422.73 \mathrm{~ns}$ & $4.77 \mathrm{~ns}$ \\
\hline Weeding $\times$ cultivar & 4 & $0.0808 * *$ & $0.019 * *$ & $3.60 \mathrm{~ns}$ & $0.44 * *$ & $622046225432 * *$ & $128839.51 * *$ & $42.82 *$ \\
\hline Year $\times$ weeding $\times$ cultivar & 4 & $0.0002 \mathrm{~ns}$ & $0.004 \mathrm{~ns}$ & $2.45 \mathrm{~ns}$ & $0.05 \mathrm{~ns}$ & $12260588395 \mathrm{~ns}$ & $2811.67 \mathrm{~ns}$ & $2.23 \mathrm{~ns}$ \\
\hline Density $\times$ weeding $\times$ cultivar & 8 & $0.0077 * *$ & $0.002 \mathrm{~ns}$ & $4.18 *$ & $0.09 * *$ & $264676453673 * *$ & $62368.84 * *$ & $19.80 \mathrm{~ns}$ \\
\hline Year $\times$ density $\times$ weeding $\times$ cultivar & 8 & $0.0002 \mathrm{~ns}$ & $0.001 \mathrm{~ns}$ & $1.83 \mathrm{~ns}$ & $0.02 \mathrm{~ns}$ & $11454575895 \mathrm{~ns}$ & $2629.31 \mathrm{~ns}$ & $2.17 \mathrm{~ns}$ \\
\hline Error in (c) & 72 & 0.0027 & 0.003 & 7.51 & 0.03 & 18566823395 & 5324.28 & 15.43 \\
\hline
\end{tabular}

DF: degrees of freedom; ns means non-significant; * and ** are significant at the probability level of $5 \%$ and $1 \%$, respectively.

\subsection{Number of lateral branches}

The results of variance analysis of measured traits showed that density, weeding, cultivar, interaction of density $\times$ weeding, weeding $\times$ cultivar, and density $\times$ weed $\times$ cultivar and interaction of density $\times$ cultivar were significant in both crop years and in compound analysis of both years with $1 \%$ probability level (Tables 1 and 2). The results of this experiment showed that density of 20 increased the number of lateral branches with means of (2.70 and 2.72 in first and second years, respectively) as compared with density of 60 with means of (2.07 and 2.15 in first and second years, respectively) (Table 3 ). Comparison of the mean of weed effect on the number of lateral branches showed that weeding at the rosette stage with means of (2.74 and 2.76 in first and second years, respectively) and non-weeding with means of ( 2.22 and 2.30 in first and second years, respectively) have the maximum and minimum numerical values, respectively (Table 5). Comparison of mean of cultivar effect on the number of lateral branches showed that Hayola 401 had the maximum number of lateral branches with means of $(3.34$ 
and 3.31 in first and second years, respectively) as compared with Sarigol cultivar with means of (1.00 and 1.30 in first and second years, respectively) (Table 7).

Morison et al. (1992) stated that in high densities, weed and chlorophyll degradation in rapeseed plant increased which resulted in an increase in the mortality caused by the competition and as a result of these changes, the yield decreased significantly. The results of many studies which are carried out on weed competition with crops did not have much effect on weed control operations, because these studies have examined the interactions of a weed species with crop, while the combination of weed species are present in the field and in practice farmers face the problem of the presence of several weed species in the fields (QEREKHLU et al., 2005). Consequently, it is necessary to address this issue further in interference studies (SEAN MOGAWELL et al., 2000). The competitive effect of several weed species on a species is very important, especially in low densities, and it is essential to predict of the mutual influence of weed species on yield (SIMS; OLIVER, 1990).

\subsection{Plant height}

Table of variance analysis indicates that density, weeding, cultivar, interaction of density $\times$ weeding, weeding $\times$ cultivar, and density $\times$ weeding $\times$ cultivar were significant in both crop years and in compound analysis of two years at $1 \%$ probability level (Tables 1 and 2 ). The results of this experiment showed that the density of 20 increased plant height with means of (154.07 and $155.02 \mathrm{~cm}$ in first and second years, respectively) as compared with density of 60 with means of (148.93 and $150.17 \mathrm{~cm}$ in first and second years, respectively) (Table 3). Comparison of mean of weeding effect on plant height showed that complete weeding with means of $(159.52$ and $159.96 \mathrm{~cm}$ in first and second years, respectively) and non-weeding with means of (141.70 and $142.93 \mathrm{~cm}$ in first and second years, respectively) have the maximum and minimum numerical values, respectively (Table 5). Comparison of mean of cultivar effect on plant height showed that Sarigol cultivar had the maximum plant height with means of $(176.48$ and $177.15 \mathrm{~cm}$ in first and second years, respectively) as compared with Heyola 401 with means of (134.62 and $135.81 \mathrm{~cm}$ in first and second years, respectively) (Table 7).

An increase in plant height is usually the most significant change in the growth of most plants. An increase in plant height can be considered as an advantage in most plants in terms of competition in plant communities. The excessive height that causes lodging and stem failure is not appropriate, but if it is accompanied by an increase in the diameter of the stem, it leads to the better distribution of the leaves in the stem and radiation is distributed more favorably in the plant community and as a result, accumulation of non-structural carbohydrates and transfer of storage materials from stem will be performed in a better way (PARASTAR, 1997).

In their research, Clewis et al. (2001) found that the plant height of Arachis hypogaea (peanut) decreased under the influence of common ragweed interference, and at all levels of interference treatment weed, height of weed was superior to crop. Mohammadi et al. (2004) led an experiment on competition between chickpea and weed and showed that, when the infestation period of weeds increases, the length of the aerial organ of chickpea decreases by $41.1 \%$ in comparison with control (whole season control).

\subsection{Distance from first branch to ground}

Table of variance analysis indicates that density, weeding, cultivar, interaction of density $\times$ weeding, weeding $\times$ cultivar, and density $\times$ cultivar were significant in both crop years and in compound analysis of two years at $1 \%$ probability level and interaction of density $\times$ weeding $\times$ cultivar was significant in the first year and at $5 \%$ probability level (Tables 1 and 2).

The mean comparison diagram showed that density of 20 increased the distance of first branch to ground with means of (13.91 and $14.09 \mathrm{~cm}$ in first and second years, respectively) as compared with density of 60 with means of (12.29 and $12.52 \mathrm{~cm}$ in first and second years, respectively) (Fig. 10). Comparison of mean of weeding effect on the distance from first branch to ground showed that complete weeding with means of $(14.99$ and $15.33 \mathrm{~cm}$ in first and second years, respectively) and non-weeding with means of (11.04 and $11.35 \mathrm{~cm}$ in first and second years, respectively) have the maximum and minimum numerical values, respectively (Fig. 11). Comparison of mean of cultivar effect on plant height showed that Sarigol cultivar with means of (36.41 and 36.78 $\mathrm{cm}$ in first and second years, respectively) had the maximum distance of first branch to ground as compared with RGS003 with means of $(1.00$ and $1.22 \mathrm{~cm}$ in first and second years, respectively) (Fig. 12).

On the other hand, increasing the competitive ability of crops is one of the key pillars of weed management that is used in sustainable agriculture and can be achieved through plant breeding, soil fertility management, and changing the crop canopy spatial arrangement (ANDERSON, 2000; BEGNA et al., 2001; TEASDALE, 1995). Moreover, Van Acker et al. (1993) and Carlson; Hill (1985) argue that plant density affects the competitive balance between weeds and crops and increases plant density, reduces weed growth and decreases the yield that is the result of competition significantly.

\subsection{Stem diameter}

Table of variance analysis indicates that density, weeding, cultivar, interaction of density $\times$ weeding and weeding $\times$ cultivar were significant in both crop years and in compound analysis of two years at $1 \%$ probability level (Tables 1 and 2).

The mean comparison diagram showed that density of 20 increased stem diameter with means of $(71.07$ and $72.69 \mathrm{~mm}$ in first and second years, respectively) as compared with density of 60 with means of (61.11 and $63.15 \mathrm{~mm}$ in first and second years, respectively) (Table 3 ). Comparison of mean of weeding effect on stem diameter showed that complete weeding with means of (72.92 and $74.46 \mathrm{~mm}$ in first and second years, respectively) and non-weeding with means of (57.25 and $59.74 \mathrm{~mm}$ in first and second years, respectively) have the maximum and minimum numerical values, respectively (Table 5). Comparison of mean of cultivar effect on stem diameter showed that RGS003 cultivar with means of (79.77 and $81.35 \mathrm{~mm}$ ) had the maximum stem diameter as compared with Hayola 401 with means of (51.18 and 53.00 $\mathrm{cm}$ in first and second years, respectively) (Table 7).

The stem diameter plays a significant role in the storage of assimilates during growing period and the possibility of transferring these materials plays an important role in filling the grains and the higher the stem diameter, the greater the 
optimum production potential in the plant (AMIRHALAJI, 2004).

In monoculture, optimum density is one of the success factors in production. If plant density is more than optimal, the existing environmental factors, including moisture, light and nutrients are not available at the optimum level for each plant, and in the contrary, if plant density is less than optimal; the existing environmental facilities are not used in a desirable manner which in turn reduces the crop. Plant density is one of the important crop factors affecting plant yield (BABAYAN et al., 1978).

Density and planting arrangement are two factors that may reduce the potential of weed interference by increasing canopy optical absorption and influence the canopy structure through the deformation of the components of aerial organs, such as leaf size, leaf orientation, and how they are connected to the stem and aging of lower canopy leaves (LOOMIS et al., 1968).

\subsection{Numbers of main stem pods}

Table of variance analysis indicates that density, weeding, cultivar, interaction of density $\times$ weeding, weeding $\times$ cultivar, density $\times$ cultivar, and density $\times$ weeding $\times$ cultivar were significant in both crop years and in compound analysis of two years at $1 \%$ probability level (Tables 1 and 2).

The mean comparison diagram showed that density of 20 increased the number of main stem pods with means of (154.63 and 156.80 in first and second years, respectively) as compared with density of 60 with means of (64.89 and 66.02 in first and second years, respectively) (Table 3). Comparison of mean of weeding effect on the number of main stem pods showed that complete weeding with means of (124.92 and 126.28 in first and second years, respectively) and nonweeding with means of (82.15 and 84.93 in first and second years, respectively) have the maximum and minimum numerical values, respectively (Table 5). Comparison of mean of cultivar effect on the number of main stem pods showed that Hyola 401 cultivar with means of (113.63 and 115.35 in first and second years, respectively) had the maximum number of stem pods as compared with RGS003 with means of (101.96 and 103.74 in first and second years, respectively) (Table 7).

Agricultural experts have argued that the establishment of an optimal plant density of healthy plants throughout the field is the basis of a successful agricultural system. When plant density is less than optimal, environmental factors such as light, moisture, and nutrients are not used at maximum level and when density is higher than optimal, intense competition reduces final yield (KHAJEHPOUR, 2004).

Maximum yield is achieved when competitions reach their minimum level and plant can make maximum use of existing growth environmental factors (GHAJARI et al., 2006). The competitive rate of weeds is not always inherited and inherent, but it depends on the conditions in which the plants compete, thus, by changing agricultural conditions, we can fight weeds better (HADIZADEH et al., 2002).

When density increases, the plant has more opportunities to absorb light, water, and nutrients. Because increased density reduces growth, biomass, and weed seed yield, and yield increases due to the absorption of more light by the canopy throughout the field (WILSON et al., 1995).

\subsection{Pod length}

Table of variance analysis indicates that density, weeding, cultivar, interaction of density $\times$ cultivar, and weeding $\times$ cultivar were significant in the first years at $1 \%$ probability level; density, weeding, cultivar, and interaction of weeding $\times$ cultivar were significant in the second year and in compound analysis of two years at $1 \%$ probability level and interaction of density $\times$ weeding $\times$ cultivar was significant in compound analysis at $5 \%$ probability level (Tables 1 and 2). The mean comparison diagram showed that density of 20 increased pod length with means of (81.48 and $82.02 \mathrm{~mm}$ in first and second years, respectively) as compared with density of 60 with means of (77.63 and 79.17 $\mathrm{mm}$ in first and second years, respectively) (Table 3 ). The results of this experiment showed that complete weeding with means of $(82.30$ and $82.29 \mathrm{~mm}$ in first and second years, respectively) and non-weeding with means of (76.18 and $77.26 \mathrm{~mm}$ in first and second years, respectively) have the maximum and minimum numerical values, respectively (Table 5). Comparison of mean of cultivar effect on pod length showed that RGS003 cultivar with means of (82.11 and $83.06 \mathrm{~mm}$ in first and second years, respectively) had the maximum pod length as compared with Sarigol cultivar with means of $(77.34$ and $78.61 \mathrm{~mm}$ in first and second years, respectively) (Table 7).

Weeds and crops do not compete to a large extent at the beginning of the growing season, but as time goes on to the point of resource constraints, competition and yield decline begin (OKI et al., 1990). Weeds are a major factor affecting crop yield, and their competition with crops is one of the most important management issues in farm management (BRIDGES; CHANDLER, 1987). Competition of weeds with crops involves a set of dynamic processes that, in combination, determine the supply, demand, attraction, and productivity of resources (BOWMAN, 2001). Competition between species or bushes has been widely investigated by researchers in order to recognize and reduce the adverse effects of weeds, optimize crop yield, and minimize seed consumption. At the beginning of the growing season when the size of seedlings is small and their needs are limited, direct interference between adjacent plants is minimal. Over time, direct interference between plants emerges, and the pressure caused by the density increases when plant size and resource constraints increase (HARPER, 1987).

\subsection{Distance from first pod to ground}

Table of variance analysis indicates that density, weeding, cultivar, interaction of density $\times$ cultivar, density $\times$ weeding, weeding $\times$ cultivar, and density $\times$ weeding $\times$ cultivar were significant in the first years at $1 \%$ probability level; density, weeding, cultivar, and interaction of weeding $\times$ cultivar were significant in the second year at $1 \%$ probability level and interaction of density $\times$ cultivar and density $\times$ weeding $\times$ cultivar were significant at $5 \%$ probability level; moreover, the results of compound analysis manifested that the effect of density, weeding, cultivar, interaction of density $\times$ weeding, density $\times$ cultivar, and weeding $\times$ cultivar were significant at $1 \%$ probability level and interaction of density $\times$ weeding $\times$ cultivar was significant at $5 \%$ probability level (Tables 1 and 2 ). The mean comparison diagram showed that density of 20 increased distance from first pod to ground with the means of 
(62.48 and $63.94 \mathrm{~cm}$ in first and second years, respectively) as compared with density of 60 with means of (59.30 and $60.28 \mathrm{~cm}$ in first and second years, respectively) (Table 3 ). The results of this experiment showed that complete weeding with means of $(65.07$ and $66.17 \mathrm{~cm}$ in first and second years, respectively) and non-weeding with means of (53.82 and $55.33 \mathrm{~cm}$ in first and second years, respectively) have the maximum and minimum numerical values, respectively (Table 5). Comparison of mean of cultivar effect on pod length showed that Sarigol cultivar with means of (89.07 and $90.11 \mathrm{~cm}$ in first and second years, respectively) had the maximum distance from first pod to ground as compared with RGS003 cultivar with means of (42.40 and $43.41 \mathrm{~cm}$ in first and second years, respectively) (Table 7).

The main reason for yield reduction is the presence of weeds, their ability to compete with the crops in utilizing the sources of light, water, and nutrients required by the plant (RAJCAN; SWANTON, 2001). The space available for plant growth may also be a factor in the creation of competition, but it can be stated that this happens when plant density is very high; otherwise, there is usually enough room for growth of the root and foliage of the plants (MAZAHERI, 1997). Zimdahl (1993) argues that weeds and crop plants that grow green at the same time (high density) rarely compete for space. However, when two species grow green at different times, the one that initially occupies space will have more competitive advantage. Competition for absorbing water, light, and nutrients is very tangible. But other types of competition need more explanations. For example, plants compete for soil oxygen although in most soils, the rate of oxygen dissipation is so rapid that sufficient volume is provided for the roots. But in very wet soils, oxygen can be a factor limiting the growth of plants. Although, in most cases, $\mathrm{CO}_{2}$ concentration of the atmosphere is always higher than the compensatory $\mathrm{CO}_{2}$ of the plant, and it is thus assumed that $\mathrm{CO}_{2}$ is not a limiting factor, in the case of canopy closure, reduction of $\mathrm{CO}_{2}$ around the canopy to a level below the atmospheric $\mathrm{CO}_{2}$ reduces yield. Therefore, the presence of weeds in crop cover can contribute to the reduction of crop yield through competition for $\mathrm{CO}_{2}$.

Various studies show that in the near future, evolution towards herbicide resistance will continue to span across vast areas of Europe and North America and will expand towards developing countries. The emergence and rapid expansion of weed resistance to herbicides also persuaded or forced many farmers to reduce the use of herbicides and the use and development of non-chemical methods of weed control (such as increasing the power and ability to compete in crops) and integrated management of these plants. Less dependence of farmers on herbicides both brings about more benefits for them and can also reduce environmental pollution (LEMERLE ET AL., 2001).

\subsection{Fresh pod weight}

Table of variance analysis indicates that density, weeding, cultivar, interaction of density $\times$ cultivar, weeding $\times$ cultivar, and density $\times$ weeding $\times$ cultivar were significant at $1 \%$ probability and in compound analysis, density, weeding, cultivar, interaction of density $\times$ cultivar, weeding $\times$ cultivar, density $\times$ weeding, and density $\times$ weeding $\times$ cultivar were significant at $1 \%$ probability level (Tables 1 and 2). The mean comparison diagram showed that densities of 20 and 40 increased fresh pod weight with mean of $(0.34 \mathrm{~g})$ in the first year and density of 20 with mean of $(0.363 \mathrm{~g})$ in the second year as compared with density of 60 with the mean of $(0.3$ and $0.311 \mathrm{~g}$ in first and second years, respectively) (Table 4). The results of this experiment showed that complete weeding with means of $(0.34$ and $0.37 \mathrm{~g}$ in first and second years, respectively) and non-weeding with means of ( 0.3 and 0.311 $\mathrm{g}$ in first and second years, respectively) have the maximum and minimum numerical values, respectively (Table 6). Comparison of mean of cultivar effect on fresh pod weight showed that Hayola 401 with means of $(0.42$ and $0.431 \mathrm{~g}$ in first and second years, respectively) had the maximum fresh pod weight as compared with Sarigol with means of $(0.26$ and $0.28 \mathrm{~g}$ in first and second years, respectively) (Table 8 ).

Increasing crop density is an effective strategy to increase the crop strength against weeds (WALKER ET AL., 2002). It has been shown in numerous studies that increasing the amount of seed used for cultivation leads to an increase in the dominance of crops to weed in monoculture systems (STANIFORTH AND WEBER, 1956). Planting density should be selected in such a way that reduced competition between crop plants will limit the growth of weeds (AHAMAD ET AL., 2007). Khan et al. (1996) have shown that doubling the amount of spring wheat seeds has increased the amount of yield as much as herbicide used to control millet.

\subsection{Dry pod weight}

Results presented in the table of variance analysis of this trait indicated that density, cultivar, interaction of density $x$ cultivar and weeding $\times$ cultivar were significant in the first year at $1 \%$ probability and interaction of density $\times$ cultivar and weeding $\times$ cultivar were significant in the second year at $1 \%$ probability level and in compound analysis of weeding at $5 \%$ probability level and cultivar, density $\times$ cultivar, and weeding $\times$ cultivar were significant at $1 \%$ probability level (Tables 1 and 2). The mean comparison diagram showed that in the first year density of 20 increased dry pod weight with mean of $(0.20 \mathrm{~g})$ and in the second year density of 40 with mean of $(0.233 \mathrm{~g})$ increased dry pod weight as compared with density of 60 with means of $(0.174$ and $0.217 \mathrm{~g}$ in first and second years, respectively) (Table 4). The results of this experiment showed that in the first year complete weeding with mean of $(0.2 \mathrm{~g})$ and in the second year weeding at the rosette stage with mean of $(0.237 \mathrm{~g})$ and non-weeding with means of $(0.17$ and $0.209 \mathrm{~g}$ in first and second years, respectively) have the maximum and minimum numerical values, respectively (Table 6). Comparison of mean of cultivar effect on dry pod weight showed that Hayola 401 with mean of $(0.23$ and $0.263 \mathrm{~g}$ in first and second years, respectively) had the maximum dry pod weight as compared with Sarigol cultivar with means of (0.181 and 0.198 grams in first and second years, respectively) (Table 8).

Like all other living organisms, weeds are affected by the environmental conditions in which they live, and they affect the neighbor creatures as closely as they are affected by beings in their vicinity. One of the most important disadvantages of weed is competition for limited resources (water, light, nutrients, carbon dioxide, etc.) (HARAMOTO; GALANT, 2005; CARRUTHERS et al., 2000; STOLLER; WOOLLEY, 1995). Weed interference with crops severely reduces the growth, yield, and quality of the crop (ZIMDAHL, 1980; QASEM, 2003). According to 
researchers, weed damage can reach 100\% (COUSENS, 1985; KROPFF; WALTER, 2000).

Weeds are more resistant than crops to adverse environmental conditions such as drought conditions, food shortages, and high and low temperatures (ASHTON, 1992). Therefore, environmental stresses such as moisture stress can increase the competitiveness of weeds as compared with crops.

\subsection{Number of seeds per pod}

Results presented in the table of variance analysis of this trait indicated that in the first year, cultivar, density, weeding, and interaction of density $x$ weeding $x$ cultivar were significant at $1 \%$ probability level and weeding $\times$ cultivar were significant at 5\% probability level and in the second year, density and weeding were significant at $1 \%$ probability level and cultivar was significant at 5\% probability level and in compound analysis, cultivar, density, and weeding were significant at $1 \%$ probability level and interaction of density $\times$ weeding $\times$ cultivar was significant at $5 \%$ probability level (Tables 1 and 2). The mean comparison diagram showed that density of 20 increased the number of seeds per pod with means of (21.40 and 22.57 in first and second years, respectively) as compared with density of 60 with means of (17.59 and 19.17 in first and second years, respectively) (Table 4). The results of this experiment showed that weeding at the rosette stage with means of (20.77 and 22.13 in first and second years, respectively) and non-weeding with means of (16.62 and 18.30 in first and second years, respectively) have the maximum and minimum numerical values, respectively (Table 6). Comparison of mean of cultivar effect on the number of seeds per pod showed that Hayola 401 with means of (20.00 and 20.9 in first and second years, respectively) had the maximum number of seeds per pod as compared with RGS003 cultivar with means of (19.00 and 20.31 in first and second years, respectively) (Table 8).

Crop seeds are considered as the photosynthetic reservoirs of the plant and whenever they are under environmental stresses such as interfering with weed, resources supplying seed reservoirs reduce due to reduced absorption of food sources and less development of photosynthesis system of plant; therefore, the size of seed decreases and, consequently, the weight of a thousand seeds decreases as well (HEJAZI, 1992).

Longer establishment and more weed stabilization in the field, and consequently intensified competition with rapeseed on growth sources, especially during grain filling are the main reasons for reducing the number of seeds per pod in weed interference treatments as compared with control treatments. This will barren some seeds at the beginning of the evolution, and consequently will reduce the number of seeds. Behdarvand et al. (2002) showed in their research that increasing the density of Avena Fatua reduced the number of seeds per spike from 7.8 to 16.1 percent as compared with control treatment (with no weed in all growing season). Yadavi et al. (2006) investigated the effect of amaranth competition on maize yield components and reported that reducing the number of seeds per ear and the number of seeds per row was the most important effect that this competition imposed on maize. In addition, in the experiment carried out by Aguya et al. (2003), the number of pods per bean plant decreased by 44 to 60 percent with an increase in the density of amaranth.

\subsection{Weight of one thousand seeds}

Results presented in the table of variance analysis of this trait indicated that cultivar, density, weeding, and interaction of density $\times$ cultivar, density $\times$ weeding $\times$ cultivar, and weeding $\times$ cultivar were significant in the first year and in compound analysis at $1 \%$ probability level; in the second year, density and weeding were significant at $1 \%$ probability level and cultivar was significant at $5 \%$ probability level (Tables 1 and 2). The mean comparison diagram showed that density of 20 increased the weight of 1000 seeds with means of (3.02 and $3.01 \mathrm{~g}$ in first and second years, respectively) as compared with density of 60 with means of (2.82 and $2.80 \mathrm{~g}$ in first and second years, respectively) (Table 4). The results of this experiment showed that complete weeding with means of (3.06 and $3.03 \mathrm{~g}$ in first and second years, respectively) and non-weeding with means of (2.70 and $2.71 \mathrm{~g}$ in first and second years, respectively) have the maximum and minimum numerical values, respectively (Table 6). Comparison of mean of cultivar effect on the weight of 1000 seeds showed that Hayola 401 with the means of (3.29 and $3.26 \mathrm{~g}$ in first and second years, respectively) had the maximum weight of 1000 seeds as compared with Sarigol cultivar with means of (2.65 and $2.63 \mathrm{~g}$ in first and second years, respectively) (Table 8).

Hamzeiee et al. (2005) concluded in their research on three cultivars of autumnal rapeseed that reduction in seed weight, which happens due to the prolonged period of weed interference, is related to the lower rate of material accumulation in the seed and shortening the effective period of grain filling. The results of the study carried out by Blackshow et al. (2005) showed that the interference of radish with rapeseed did not have any significant effect on the weight of 1000 seeds of rapeseed.

\subsection{Seed yield}

Results presented in the table of variance analysis of this trait indicated that cultivar, density, weeding, and interaction of weeding $\times$ cultivar, density $\times$ cultivar, density $\times$ weeding, and density $\times$ weeding $\times$ cultivar were significant in both crop years and in compound analysis of two years at $1 \%$ probability level (Tables 1 and 2). The mean comparison diagram showed that density of 20 increased seed yield with means of (2497296 and $2483963 \mathrm{~g}$ in first and second years, respectively) as compared with density of 60 with means of (2015074 and $2045663 \mathrm{~g}$ in first and second years, respectively) (Table 4). The results of this experiment showed that complete weeding with means of (2735630 and $2757963 \mathrm{~g}$ in first and second years, respectively) and nonweeding with means of (1257741 and $1282169 \mathrm{~g}$ in first and second years, respectively) had the maximum and minimum numerical values, respectively (Table 6). Comparison of mean of cultivar effect on seed yield showed that Hayola 401 with means of (2587333 and $2587407 \mathrm{~g}$ in first and second years, respectively) had the maximum seed yield as compared with Sarigol cultivar with means of (81813333 and $1835943 \mathrm{~g}$ in first and second years, respectively) (Table 8).

Taylor and Smith (1992) reported that seed yield in rapeseed is a function of the number of pods per unit area, the number of seeds per pod and the weight of a thousand seeds. 
If the weeds of the fields are not controlled, the yield of crops decreases from 10 to $100 \%$ depending on the competitive ability of weeds. On the other hand, despite vigorous control in most agricultural systems, weed competition leads to a $10 \%$ reduction in agricultural yields (KROPFF AND WANLAAR, 1993). Busan and Maxwell (2000) reported that densities of 60 to 90 plants of Avena Fatua per square meter resulted in a 55 percent reduction in yield. McMullan (1994) argued that the presence of 10 Sinapis arvensis plants per square meter of rapeseed farm reduced the rapeseed yield by $20 \%$.

\subsection{Oil yield}

Results presented in the table of variance analysis of this trait indicated that cultivar, density, weeding, and interaction of weeding $\times$ cultivar, density $\times$ cultivar, density $\times$ weeding, and density $\times$ weeding $\times$ cultivar were significant in both crop years and in compound analysis of two years at $1 \%$ probability level. The mean comparison diagram showed that in the first year density of 20 with mean of $(1187.17 \mathrm{~kg}$ per hectare) and in the second year density of 40 with mean of (1180.39 kg per hectare) increased the oil yield as compared with density of 60 with means of $(967.14$ and $981.65 \mathrm{~kg}$ per hectare in the first and second years, respectively) (Table 4). The results of this experiment showed that complete weeding with means of (1299.48 and $1309.79 \mathrm{~kg}$ per hectare in first and second years, respectively) and non-weeding with means of $(618.94$ and $6230.82 \mathrm{~kg}$ per hectare in first and second years, respectively) have the maximum and minimum numerical values, respectively (Table 6). Comparison of mean of cultivar effect on seed yield showed that Hayola 401 with means of (1239.35 and $1238.93 \mathrm{~kg}$ per hectare in first and second years, respectively) had the maximum oil yield as compared with RGS003 cultivar with means of (873.2 and $884.3 \mathrm{~kg}$ per hectare in first and second years, respectively) (Table 8).

Freyson (1986) examined the effect of weed interference on the yield and quality of flaxseed oil and showed that seed oil content decreased in the plots that had weed. Moreover, Miri (2003) reported that seed oil percentage is not affected by weed condition.

\subsection{Oil percentage}

Results presented in the table of variance analysis of this trait indicated that in the first year density, weeding, and cultivar were significant at $1 \%$ probability level, in the second year density, weeding, cultivar, and interaction of weeding $\times$ cultivar were significant at $1 \%$ probability level and density $\times$ cultivar was significant at $5 \%$ probability level and in compound analysis, density, weeding, and cultivar were significant at $1 \%$ probability level and weeding $\times$ cultivar was significant at 5\% probability level (Tables 1 and 2 ). The mean comparison diagram showed that density of 20 increased oil percentage with means of (37.62 and 37.13 in first and second years, respectively) as compared with density of 60 with means of (34.72 and 34.24 in first and second years, respectively) (Table 4). The results of this experiment showed that weeding at the rosette stage with means of (40.16 and 40.23 in first and second years, respectively) and non-weeding with means of (30.22 and 29.71 in first and second years, respectively) have the maximum and minimum numerical values, respectively (Table 6). Comparison of mean of cultivar effect on oil percentage showed that Hayola 401 with means of (38.09 and 38.11 in first and second years, respectively) had the maximum oil percentage as compared with RGS003 cultivar with means of (33.65 and 33.26 in first and second years, respectively) (Table 8$)$.

\section{CONCLUSIONS}

The results of this experiment showed that density of 20 plants per $\mathrm{m}^{-2}$ increased leaf area, number of lateral branches, plant height, stem diameter, number of pods of main stem, pod length, distance from first pod to ground, fresh pod weight, number of seeds per pod, weight of 1000 seeds, and seed and oil yields as compared with density of 60 plants per $\mathrm{m}^{-2}$.

Comparison of mean of weeding effect on leaf area, plant height, number of main stem pods, distance from first branch to ground, stem diameter, pod length, distance from the first pod to ground, fresh pod weight, weight of 1000 seeds, seed and oil yield showed that complete weeding and nonweeding have the maximum and minimum numerical values, respectively.

Comparison of mean of cultivar effect on leaf area, plant height, and distance from first pod to ground showed that Sarigol had the maximum leaf area as compared with Hayola 401.

Also, the results showed that Hyola 401 cultivar had more yield than other cultivars.

\section{REFERENCES}

AHMADI, A.; BAZGIR, A.; MOUSAVI, S. K. Effect of date and density of planting on interference of weeds on pea field in Lorestan. In: CONGRESS OF WEED SCIENCE IN IRAN, 2nd. Proceedings... 2007, p. 15-17. (In Persian with English summary).

ANDERSON, R. L. Cultural systems to aid weed management in semiarid corn (Zea mays). Weed Technology, Champaign, v. 14, n. 3, p. 630-634, 2000. DOI: $\quad$ https://doi.org/10.1614/0890037X(2000)014[0630:CSTAWM]2.0.CO;2

BABAYAN, V. K.; KOOTUNGAL, D.; HALABY, G. A. Proximate analysis, fatty acid and, amino acid composition of (Nigella sativa L.) seed. Journal of Food Science, Champaign, v. 43, n. 4, p. 1315-1319, 1978. DOI: https://doi.org/10.1111/j.1365-2621.1978.tb15297.x

BEGNA, S. H.; HAMILTON, R. I.; DWYER, L. M.; STEWART, D. W.; CLOUTIER, D.; ASSEMAT, L.; FOROUTAN POUR, K.; SMITH, D. L. Weed biomass production response to plant spacing and corn (Zea mays) hybrids differing in canopy architecture. Weed Technology, Champaign, v. 15, n. 4, p. 647-665, 2001. DOI: https://doi.org/10.1614/0890037X(2001)015[0647:WBPRTP]2.0.CO;2

BLACKSHOW, R. E. Differential competitive ability of winter wheat cultivarst downy room. Agronomy Journal, v. 86, p. 649-654, 1994.

BRIDGES, D. C; CHANDLER, J. M. Effect of herbicide and weed height on Johnson grass (Sorghum halepense) control and cotton yield. Weed Techonology, v. 1, p. 207-221, 1987.

CARLSON, H. L.; HILL, J. E. Weed oat competition with spring wheat: plant density effects. Weed Science, v. 33, p. 176-181, 1985. 


\begin{tabular}{|c|c|c|c|c|c|c|c|c|c|c|c|c|c|c|c|c|c|}
\hline \multirow[t]{2}{*}{$\begin{array}{l}\text { Change } \\
\text { sources }\end{array}$} & \multirow[t]{2}{*}{ DF } & \multicolumn{2}{|c|}{ Leaf area } & \multicolumn{2}{|c|}{$\begin{array}{c}\text { Number of lateral } \\
\text { branches }\end{array}$} & \multicolumn{2}{|c|}{ Plant height } & \multicolumn{2}{|c|}{$\begin{array}{l}\text { Distance from first } \\
\text { branch to ground }\end{array}$} & \multicolumn{2}{|c|}{ Stem diameter } & \multicolumn{2}{|c|}{$\begin{array}{l}\text { Number of main stem } \\
\text { pods }\end{array}$} & \multicolumn{2}{|c|}{ Pod length } & \multicolumn{2}{|c|}{$\begin{array}{l}\text { Distance from first pod to } \\
\text { ground }\end{array}$} \\
\hline & & $\begin{array}{l}2015- \\
2016\end{array}$ & $\begin{array}{l}2016- \\
2017\end{array}$ & $\begin{array}{l}2015- \\
2016\end{array}$ & $\begin{array}{c}2016- \\
2017\end{array}$ & $\begin{array}{l}2015- \\
2016\end{array}$ & $\begin{array}{l}2016- \\
2017\end{array}$ & $\begin{array}{l}2015- \\
2016 \\
\end{array}$ & $\begin{array}{r}2016- \\
2017 \\
\end{array}$ & $\begin{array}{l}2015- \\
2016\end{array}$ & $\begin{array}{l}2016- \\
2017\end{array}$ & $\begin{array}{l}2015- \\
2016\end{array}$ & $\begin{array}{c}2016- \\
2017\end{array}$ & $\begin{array}{l}2015- \\
2016\end{array}$ & $\begin{array}{l}2016- \\
2017\end{array}$ & $\begin{array}{l}2015- \\
2016\end{array}$ & $\begin{array}{c}2016- \\
2017\end{array}$ \\
\hline Block & 2 & $1.15 \mathrm{~ns}$ & $3.02 \mathrm{~ns}$ & $0.09 \mathrm{~ns}$ & $1.06^{* *}$ & $10.53 \mathrm{~ns}$ & $130.30 * *$ & $0.07 \mathrm{~ns}$ & $5.07 \mathrm{~ns}$ & $9.83 \mathrm{~ns}$ & $15.72 \mathrm{~ns}$ & $7.15 \mathrm{~ns}$ & $52.02 \mathrm{~ns}$ & $0.75 \mathrm{~ns}$ & $8.91 \mathrm{~ns}$ & $25.02 \mathrm{~ns}$ & $5.38 \mathrm{~ns}$ \\
\hline Density (a) & 2 & $246.26^{* *}$ & $542.00 * *$ & $3.05^{* *}$ & $5.27 * *$ & $203.35^{* *}$ & $389.80^{* *}$ & $19.72 * *$ & $35.28 * *$ & $683.05^{* *}$ & $1256.02 * *$ & $54525.15^{* *}$ & $111430.78^{* *}$ & $109.83^{* *}$ & $133.43 * *$ & $216.22 * *$ & $85.38 * *$ \\
\hline Error in a & 4 & 2.41 & 6.30 & 0.07 & 0.15 & 16.40 & 33.48 & 0.45 & 2.27 & 2.18 & 13.82 & 2.24 & 20.95 & 4.96 & 15.66 & 7.88 & 0.31 \\
\hline Weeding (b) & 2 & $720.44 * *$ & $1399.02 * *$ & $1.86^{* *}$ & $2.97 * *$ & $2151.57 * *$ & $3956.07 * *$ & $106.07 * *$ & $217.02 * *$ & $1815.79 * *$ & $3171.72 * *$ & $14215.44 * *$ & $26730.30 * *$ & $287.42 * *$ & $571.41 * *$ & $1715.06^{* *}$ & $934.72 * *$ \\
\hline $\mathrm{a} \times \mathrm{b}$ & 4 & $8.09 * *$ & $22.60 * *$ & $0.35^{* *}$ & $0.51 * *$ & $43.05^{* *}$ & $69.84 * *$ & $2.99 * *$ & $2.84 \mathrm{~ns}$ & $23.36^{* *}$ & $59.02 * *$ & $364.98 * *$ & $526.98 * *$ & $2.23 \mathrm{~ns}$ & $6.02 \mathrm{~ns}$ & $37.06^{* *}$ & $14.25^{* *}$ \\
\hline Error in $b$ & 12 & 1.21 & 4.81 & 0.09 & 0.27 & 2.76 & 8.40 & 1.02 & 4.42 & 3.51 & 11.92 & 2.64 & 21.00 & 1.59 & 8.40 & 9.59 & 2.28 \\
\hline Cultivar (c) & 2 & $880.70 * *$ & $1870.80 * *$ & $43.57^{* *}$ & $77.52^{* *}$ & $13540.79 * *$ & 26426.00 ** & $11153.67^{* *}$ & $22530.05 * *$ & $5601.38^{* *}$ & $11068.69^{* *}$ & $942.11 * *$ & $1923.56^{* *}$ & $156.68^{* *}$ & $269.65^{* *}$ & $33678.69^{* *}$ & $16982.72 * *$ \\
\hline$a \times c$ & 4 & $1.24 \mathrm{~ns}$ & $3.30 \mathrm{~ns}$ & $1.33^{* *}$ & $2.48 * *$ & $4.05 \mathrm{~ns}$ & $7.94 \mathrm{~ns}$ & $14.05^{* *}$ & $24.60 * *$ & $2.07 \mathrm{~ns}$ & $12.98 \mathrm{~ns}$ & $372.65^{* *}$ & $578.18^{* *}$ & $8.49 * *$ & $8.40 \mathrm{~ns}$ & $25.24 *$ & $9.86 * *$ \\
\hline $\mathrm{b} \times \mathrm{c}$ & 4 & $35.87^{* *}$ & $74.59 * *$ & $0.81^{* *}$ & $0.99 * *$ & $47.72 * *$ & $73.32 * *$ & $84.50 * *$ & $174.82 * *$ & $62.20 * *$ & $118.30 * *$ & $55.11 * *$ & $145.76 * *$ & $7.20^{* *}$ & $28.16^{* *}$ & $107.69 * *$ & $60.42 * *$ \\
\hline$a \times b \times c$ & 8 & $16.32 * *$ & $34.61 * *$ & $0.23 * *$ & $0.47 * *$ & $12.48^{* *}$ & $35.20 * *$ & $1.81^{*}$ & $2.09 \mathrm{~ns}$ & $5.49 \mathrm{~ns}$ & $11.25 \mathrm{~ns}$ & $199.37 * *$ & $329.17 * *$ & $1.54 \mathrm{~ns}$ & $9.83 \mathrm{~ns}$ & $18.03 *$ & $8.85^{* *}$ \\
\hline Error in $\mathrm{c}$ & 36 & 1.80 & 2.51 & 0.05 & 0.11 & 4.15 & 10.39 & 0.80 & 2.32 & 4.30 & 12.53 & 2.99 & 24.69 & 1.21 & 6.66 & 8.79 & 3.11 \\
\hline & & 1.54 & 1.81 & 9.05 & 13.47 & 1.35 & 2.12 & 6.90 & 11.53 & 3.12 & 5.18 & 1.60 & 4.50 & 1.38 & 3.19 & 4.81 & 2.92 \\
\hline
\end{tabular}

DF: degrees of freedom; CV: Coefficient of variation; Ns means non-significant; * and ** are significant at the probability level of $5 \%$ and $1 \%$, respectively.

Table 2. Continued (Average of squares)

\begin{tabular}{|c|c|c|c|c|c|c|c|c|c|c|c|c|c|c|c|}
\hline \multirow{2}{*}{$\begin{array}{l}\text { Change } \\
\text { sources }\end{array}$} & \multirow{2}{*}{ DF } & \multicolumn{2}{|c|}{ Fresh pod weight } & \multicolumn{2}{|c|}{ Dry pod weight } & \multicolumn{2}{|c|}{$\begin{array}{l}\text { Number of seeds per } \\
\text { pod }\end{array}$} & \multicolumn{2}{|c|}{ Weight of 1000 seeds } & \multicolumn{2}{|c|}{ Yield per hectare } & \multicolumn{2}{|c|}{ Oil yield } & \multicolumn{2}{|c|}{ Oil percentage } \\
\hline & & $\begin{array}{l}2015- \\
2016 \\
\end{array}$ & $\begin{array}{l}2016- \\
2017 \\
\end{array}$ & $\begin{array}{l}2015- \\
2016 \\
\end{array}$ & $\begin{array}{c}2016- \\
2017 \\
\end{array}$ & $\begin{array}{l}2015- \\
2016 \\
\end{array}$ & $\begin{array}{l}2016- \\
2017 \\
\end{array}$ & $\begin{array}{l}2015- \\
2016 \\
\end{array}$ & $\begin{array}{l}2016- \\
2017 \\
\end{array}$ & $\begin{array}{l}2015- \\
2016 \\
\end{array}$ & $\begin{array}{l}2016- \\
2017 \\
\end{array}$ & $\begin{array}{l}2015- \\
2016 \\
\end{array}$ & $\begin{array}{l}2016- \\
2017 \\
\end{array}$ & $\begin{array}{l}2015- \\
2016 \\
\end{array}$ & $\begin{array}{c}2016- \\
2017 \\
\end{array}$ \\
\hline Block & 2 & $0.0009 \mathrm{~ns}$ & $0.031^{* *}$ & $0.0009 \mathrm{~ns}$ & $0.007 \mathrm{~ns}$ & $0.70 \mathrm{~ns}$ & $15.72 *$ & $0.005 \mathrm{~ns}$ & $0.21 * *$ & $48592456790^{* *}$ & $155821572654.00^{* *}$ & $4144.66 \mathrm{~ns}$ & $26042.19 * *$ & $28.23 \mathrm{~ns}$ & $20.95 \mathrm{~ns}$ \\
\hline Density (a) & 2 & $0.0149 * *$ & $0.042 * *$ & $0.0060^{* *}$ & $0.005 \mathrm{~ns}$ & $99.59 * *$ & $157.24 * *$ & $0.326^{* *}$ & $0.64 * *$ & $1895547500000^{* *}$ & $3136960000000.00^{* *}$ & $373561.68^{* *}$ & $606738.35^{* *}$ & $90.88 * *$ & $134.97 * *$ \\
\hline Error in a & 4 & 0.0005 & $0.002 \mathrm{~ns}$ & 0.0001 & 0.001 & 0.41 & 5.91 & 0.003 & 0.09 & $2,041 \mathrm{E}+10$ & 39673043951.00 & 3125.72 & 4931.71 & 36.56 & 62.76 \\
\hline Weeding (b) & 2 & $0.0164 * *$ & $0.037 * *$ & $0.0053 \mathrm{~ns}$ & $0.013 \mathrm{~ns}$ & $152.15^{* *}$ & $257.06^{* *}$ & $1.057^{* *}$ & $1.80^{* *}$ & $17856902000000^{* *}$ & $35056890000000.00 * *$ & $3840603.93 * *$ & $7518776.84^{* *}$ & $927.75^{* *}$ & $1687.08^{* *}$ \\
\hline $\mathrm{a} \times \mathrm{b}$ & 4 & $0.0038 \mathrm{~ns}$ & $0.010^{* *}$ & $0.0018 \mathrm{~ns}$ & $0.002 \mathrm{~ns}$ & $0.19 \mathrm{~ns}$ & $1.24 \mathrm{~ns}$ & $0.004 \mathrm{~ns}$ & $0.02 \mathrm{~ns}$ & $222614530864 * *$ & $496804064877.00 * *$ & $35097.52 * *$ & $72299.98^{* *}$ & $19.66 \mathrm{~ns}$ & $24.79 \mathrm{~ns}$ \\
\hline Error in $b$ & 12 & 0.0021 & 0.004 & 0.0011 & 0.002 & 0.25 & & 0.005 & 0.05 & 9252265432.10 & 22169975741.00 & 2671.14 & 5603.01 & 69.34 & 128.80 \\
\hline Cultivar (c) & 2 & $0.1783 * *$ & $0.332 * *$ & $0.0423 * *$ & $0.059^{* *}$ & $8.11 * *$ & $17.91^{*}$ & $2.522^{* *}$ & $5.37 * *$ & $4048417300000^{* *}$ & $7627151400000.00^{* *}$ & $905704.12^{* *}$ & $1700884.22 * *$ & $196.96^{* *}$ & $340.78 * *$ \\
\hline$a \times c$ & 4 & $0.0185^{* *}$ & $0.040 * *$ & $0.0088^{* *}$ & $0.016^{* *}$ & $0.43 \mathrm{~ns}$ & $2.56 \mathrm{~ns}$ & $0.037^{* *}$ & $0.15^{* *}$ & $192232956790^{* *}$ & $494067589321.00 * *$ & $41879.57 * *$ & $104486.44 * *$ & $25.48 \mathrm{~ns}$ & $29.92 *$ \\
\hline $\mathrm{b} \times \mathrm{c}$ & 4 & $0.0394 * *$ & $0.081^{* *}$ & $0.0092 * *$ & $0.019 * *$ & $1.37^{*}$ & $3.60 \mathrm{~ns}$ & $0.146^{* *}$ & $0.44 * *$ & $324758790123^{* *}$ & $622046225432.00 * *$ & $69135.51 * *$ & $128839.51^{* *}$ & $27.94 \mathrm{~ns}$ & $42.82 * *$ \\
\hline$a \times b \times c$ & 8 & $0.0043 \mathrm{~ns}$ & $0.008 * *$ & $0.0023 \mathrm{~ns}$ & $0.002 \mathrm{~ns}$ & $1.41^{* *}$ & $4.18 \mathrm{~ns}$ & $0.040^{* *}$ & $0.09 * *$ & $112322614198^{* *}$ & $264676453673.00^{* *}$ & $27174.80 * *$ & $62368.84 * *$ & $13.80 \mathrm{~ns}$ & $19.80 \mathrm{~ns}$ \\
\hline Error in $\mathrm{c}$ & 36 & 0.0025 & 0.003 & 0.0020 & 0.005 & 0.52 & 4.81 & 0.002 & 0.04 & 11481117284.00 & 16784767051.00 & 4366.19 & 4514.46 & 17.77 & 10.85 \\
\hline CV (\%) & & 15.38 & 16.21 & 23.38 & 29.72 & 4.04 & 10.54 & 1.44 & 6.53 & 4.89 & 5.87 & 6.27 & 6.34 & 11.76 & 9.14 \\
\hline
\end{tabular}

DF: degrees of freedom; CV: Coefficient of variation; Ns means non-significant; * and ** are significant at the probability level of $5 \%$ and $1 \%$, respectively.

Table 3. Comparison of mean of studied densities in terms of agronomic traits.

\begin{tabular}{|c|c|c|c|c|c|c|c|c|c|c|c|c|c|c|c|c|}
\hline \multirow{2}{*}{$\begin{array}{c}\text { Density } \\
\text { (plants } \mathrm{m}^{-2} \text { ) }\end{array}$} & \multicolumn{2}{|c|}{ Leaf area } & \multicolumn{2}{|c|}{$\begin{array}{c}\text { Number of lateral } \\
\text { branches }\end{array}$} & \multicolumn{2}{|c|}{ Plant height } & \multicolumn{2}{|c|}{$\begin{array}{l}\text { Distance from first } \\
\text { branch to ground }\end{array}$} & \multicolumn{2}{|c|}{ Stem diameter } & \multicolumn{2}{|c|}{$\begin{array}{l}\text { Number of main } \\
\text { stem pods }\end{array}$} & \multicolumn{2}{|c|}{ Pod length } & \multicolumn{2}{|c|}{$\begin{array}{l}\text { Distance from first } \\
\text { pod to ground }\end{array}$} \\
\hline & $\begin{array}{r}2015- \\
2016 \\
\end{array}$ & $\begin{array}{l}2016- \\
2017 \\
\end{array}$ & $\begin{array}{l}2015- \\
2016 \\
\end{array}$ & $\begin{array}{c}2016- \\
2017 \\
\end{array}$ & $\begin{array}{l}2015- \\
2016 \\
\end{array}$ & $\begin{array}{l}2016- \\
2017 \\
\end{array}$ & $\begin{array}{l}2015- \\
2016 \\
\end{array}$ & $\begin{array}{l}2016- \\
2017 \\
\end{array}$ & $\begin{array}{l}2015- \\
2016 \\
\end{array}$ & $\begin{array}{l}2016- \\
2017 \\
\end{array}$ & $\begin{array}{l}2015- \\
2016 \\
\end{array}$ & $\begin{array}{l}2016- \\
2017 \\
\end{array}$ & $\begin{array}{l}2015- \\
2016 \\
\end{array}$ & $\begin{array}{l}2016- \\
2017 \\
\end{array}$ & $\begin{array}{l}2015- \\
2016 \\
\end{array}$ & $\begin{array}{l}2016- \\
2017 \\
\end{array}$ \\
\hline 20 & $90.87 \mathrm{a}$ & $90.48 \mathrm{a}$ & $2.72 \mathrm{a}$ & $2.7037 \mathrm{a}$ & $155.02 \mathrm{a}$ & $154.074 \mathrm{a}$ & $14.09 \mathrm{a}$ & $13.9074 a$ & $72.69 \mathrm{a}$ & $71.07 \mathrm{a}$ & $156.80 \mathrm{a}$ & $154.62 \mathrm{a}$ & $82.06 a$ & $81.48 \mathrm{a}$ & $63.94 \mathrm{a}$ & $62.48 \mathrm{a}$ \\
\hline 40 & $87.54 \mathrm{~b}$ & $87.30 \mathrm{~b}$ & $2.65 \mathrm{a}$ & $2.5925 \mathrm{a}$ & $150.59 b$ & $149.852 b$ & $12.97 \mathrm{~b}$ & $12.6222 \mathrm{~b}$ & $69.17 \mathrm{~b}$ & $67.29 \mathrm{~b}$ & $108.22 b$ & $105.48 \mathrm{~b}$ & $81.69 a$ & $80.59 \mathrm{a}$ & $60.72 \mathrm{~b}$ & $59.51 b$ \\
\hline 60 & $84.54 \mathrm{c}$ & $84.44 \mathrm{c}$ & $2.15 \mathrm{~b}$ & $2.0740 \mathrm{~b}$ & $150.17 \mathrm{~b}$ & $148.926 \mathrm{~b}$ & $12.52 \mathrm{~b}$ & $12.2889 \mathrm{~b}$ & $63.15 \mathrm{c}$ & $61.11 \mathrm{c}$ & $66.02 \mathrm{c}$ & $64.88 \mathrm{c}$ & $79.17 b$ & $77.62 \mathrm{~b}$ & $60.28 \mathrm{~b}$ & $59.29 \mathrm{~b}$ \\
\hline
\end{tabular}


The effect of planting density and weed interference on agricultural traits of different rapeseed genotypes in Darab Region ...

Table 4. Comparison of mean of studied densities in terms of agronomic traits.

\begin{tabular}{|c|c|c|c|c|c|c|c|c|c|c|c|c|c|c|}
\hline \multirow{2}{*}{$\begin{array}{c}\text { Density } \\
\left(\text { plants } \mathrm{m}^{-2} \text { ) }\right.\end{array}$} & \multicolumn{2}{|c|}{ Fresh pod weight } & \multicolumn{2}{|c|}{ Dry pod weight } & \multicolumn{2}{|c|}{ Number of seeds per pod } & \multicolumn{2}{|c|}{ Weight of 1000 seeds } & \multicolumn{2}{|c|}{ Yield per hectare } & \multicolumn{2}{|c|}{ Oil yield } & \multicolumn{2}{|c|}{ Oil percentage } \\
\hline & $\begin{array}{l}2015- \\
2016\end{array}$ & $\begin{array}{l}2016- \\
2017 \\
\end{array}$ & $\begin{array}{l}2015- \\
2016 \\
\end{array}$ & $\begin{array}{c}2016- \\
2017 \\
\end{array}$ & $\begin{array}{c}2015- \\
2016 \\
\end{array}$ & 2016-2017 & $\begin{array}{c}2015- \\
2016 \\
\end{array}$ & $\begin{array}{l}2016- \\
2017 \\
\end{array}$ & $\begin{array}{l}2015- \\
2016\end{array}$ & $\begin{array}{l}2016- \\
2017\end{array}$ & $\begin{array}{l}2015- \\
2016 \\
\end{array}$ & $\begin{array}{c}2016- \\
2017\end{array}$ & $\begin{array}{l}2015- \\
2016\end{array}$ & $\begin{array}{l}2016- \\
2017 \\
\end{array}$ \\
\hline 20 & $0.363 \mathrm{a}$ & $0.340 \mathrm{a}$ & $0.231 \mathrm{~b}$ & $0.203 \mathrm{a}$ & $22.57 \mathrm{a}$ & $21.40 \mathrm{a}$ & $3.01 \mathrm{a}$ & $3.01 \mathrm{a}$ & $2483963 a$ & $2497296 a$ & $1017.12 \mathrm{~b}$ & $1187.17 \mathrm{a}$ & $37.13 \mathrm{a}$ & $37.62 \mathrm{a}$ \\
\hline 40 & $0.356 \mathrm{a}$ & $0.340 \mathrm{a}$ & $0.233 \mathrm{a}$ & $0.192 b$ & $20.70 \mathrm{~b}$ & $19.11 \mathrm{~b}$ & $2.95 \mathrm{ab}$ & $2.97 \mathrm{a}$ & $2091037 b$ & $2065889 \mathrm{~b}$ & $1180.39 \mathrm{a}$ & $1005.06 \mathrm{~b}$ & $36.80 \mathrm{a}$ & $36.46 \mathrm{a}$ \\
\hline 60 & $0.311 \mathrm{~b}$ & $0.300 \mathrm{~b}$ & $0.217 \mathrm{a}$ & $0.174 \mathrm{c}$ & $19.17 \mathrm{c}$ & $17.59 \mathrm{c}$ & $2.80 \mathrm{~b}$ & $2.81 \mathrm{~b}$ & $2045669 \mathrm{~b}$ & $2015074 b$ & $981.65 b$ & $967.14 b$ & $34.24 \mathrm{a}$ & $34.74 \mathrm{a}$ \\
\hline
\end{tabular}

Table 5. Comparison of mean of studied weeding type in terms of agronomic traits.

\begin{tabular}{|c|c|c|c|c|c|c|c|c|c|c|c|c|c|c|c|c|}
\hline \multirow{2}{*}{ Weeding } & \multicolumn{2}{|c|}{ Leaf area } & \multicolumn{2}{|c|}{$\begin{array}{l}\text { Number of } \\
\text { lateral branches }\end{array}$} & \multicolumn{2}{|c|}{ Plant height } & \multicolumn{2}{|c|}{$\begin{array}{l}\text { Distance from first } \\
\text { branch to ground }\end{array}$} & \multicolumn{2}{|c|}{ Stem diameter } & \multicolumn{2}{|c|}{$\begin{array}{l}\text { Number of main } \\
\text { stem pods }\end{array}$} & \multicolumn{2}{|c|}{ Pod length } & \multicolumn{2}{|c|}{$\begin{array}{l}\text { Distance from first pod } \\
\text { to ground }\end{array}$} \\
\hline & $\begin{array}{r}2015- \\
2016 \\
\end{array}$ & $\begin{array}{r}2016- \\
2017 \\
\end{array}$ & $\begin{array}{l}2015- \\
2016 \\
\end{array}$ & $\begin{array}{l}2016- \\
2017 \\
\end{array}$ & $\begin{array}{l}2015- \\
2016 \\
\end{array}$ & $\begin{array}{l}2016- \\
2017 \\
\end{array}$ & $\begin{array}{c}2015- \\
2016 \\
\end{array}$ & $\begin{array}{l}2016- \\
2017 \\
\end{array}$ & $\begin{array}{l}2015- \\
2016 \\
\end{array}$ & $\begin{array}{r}2016- \\
2017 \\
\end{array}$ & $\begin{array}{l}2015- \\
2016 \\
\end{array}$ & $\begin{array}{l}2016- \\
2017 \\
\end{array}$ & $\begin{array}{r}2015- \\
2016 \\
\end{array}$ & $\begin{array}{l}2016- \\
2017 \\
\end{array}$ & $\begin{array}{c}2015- \\
2016 \\
\end{array}$ & 2016-2017 \\
\hline Complete weeding & $91.39 \mathrm{a}$ & $91.33 \mathrm{a}$ & $2.46 \mathrm{~b}$ & $2.40 \mathrm{~b}$ & $159.96 \mathrm{a}$ & $159.51 \mathrm{a}$ & $15.33 \mathrm{a}$ & $14.99 \mathrm{a}$ & $74.46 a$ & $72.92 \mathrm{a}$ & $126.28 \mathrm{a}$ & $124.92 \mathrm{a}$ & $83.33 \mathrm{a}$ & $82.29 a$ & $66.17 \mathrm{a}$ & $65.07 \mathrm{a}$ \\
\hline Weeding at the rosette stage & $89.70 \mathrm{~b}$ & $89.33 \mathrm{~b}$ & $2.76 \mathrm{a}$ & $2.74 \mathrm{a}$ & $152.89 \mathrm{~b}$ & $151.62 \mathrm{~b}$ & $12.90 \mathrm{~b}$ & $12.78 \mathrm{~b}$ & $70.80 \mathrm{~b}$ & $69.29 \mathrm{~b}$ & $119.83 b$ & $117.92 \mathrm{~b}$ & $82.31 \mathrm{~b}$ & $81.22 \mathrm{~b}$ & $63.44 \mathrm{~b}$ & $62.40 \mathrm{~b}$ \\
\hline Non-weeding & $81.85 \mathrm{c}$ & $81.56 \mathrm{c}$ & $2.30 \mathrm{~b}$ & $2.22 \mathrm{c}$ & $142.93 \mathrm{c}$ & $141.70 \mathrm{c}$ & $11.35 \mathrm{c}$ & $11.03 \mathrm{c}$ & $59.74 \mathrm{c}$ & $57.25 \mathrm{c}$ & $84.93 \mathrm{c}$ & $82.14 \mathrm{c}$ & $77.26 \mathrm{c}$ & $76.18 \mathrm{c}$ & $55.33 \mathrm{c}$ & $53.81 \mathrm{c}$ \\
\hline
\end{tabular}

Table 6. Comparison of mean of studied weeding type in terms of agronomic traits.

\begin{tabular}{|c|c|c|c|c|c|c|c|c|c|c|c|c|c|c|}
\hline \multirow[b]{2}{*}{ Weeding } & \multicolumn{2}{|c|}{ Fresh pod weight } & \multicolumn{2}{|c|}{ Dry pod weight } & \multicolumn{2}{|c|}{ Number of seeds per pod } & \multicolumn{2}{|c|}{ Weight of 1000 seeds } & \multicolumn{2}{|c|}{ Yield per hectare } & \multicolumn{2}{|c|}{ Oil yield } & \multicolumn{2}{|c|}{ Oil percentage } \\
\hline & $\begin{array}{l}2015- \\
2016\end{array}$ & $\begin{array}{l}2016- \\
2017\end{array}$ & $\begin{array}{l}2015- \\
2016\end{array}$ & $\begin{array}{l}2016- \\
2017\end{array}$ & $\begin{array}{c}2015- \\
2016\end{array}$ & $\begin{array}{l}2016- \\
2017\end{array}$ & $\begin{array}{l}2015- \\
2016\end{array}$ & $\begin{array}{l}2016- \\
2017\end{array}$ & $\begin{array}{l}2015- \\
2016\end{array}$ & $\begin{array}{l}2016- \\
2017\end{array}$ & $\begin{array}{l}2015- \\
2016\end{array}$ & $\begin{array}{c}2016- \\
2017\end{array}$ & $\begin{array}{l}2015- \\
2016\end{array}$ & $\begin{array}{l}2016- \\
2017\end{array}$ \\
\hline Complete weeding & $0.370 \mathrm{a}$ & $0.348 \mathrm{a}$ & $0.235 \mathrm{a}$ & $0.200 \mathrm{a}$ & $22.02 \mathrm{a}$ & $20.70 \mathrm{a}$ & $3.03 \mathrm{a}$ & $3.05 \mathrm{a}$ & $2757963 a$ & $2735630 \mathrm{a}$ & $1309.79 \mathrm{a}$ & $1299.48 \mathrm{a}$ & $38.24 \mathrm{a}$ & $38.45 \mathrm{a}$ \\
\hline Weeding at the rosette stage & $0.341 \mathrm{~b}$ & $0.333 \mathrm{a}$ & $0.237 \mathrm{a}$ & $0.196 a b$ & $22.13 \mathrm{a}$ & $20.77 \mathrm{a}$ & $3.02 \mathrm{a}$ & $3.04 \mathrm{a}$ & $2580537 \mathrm{~b}$ & $2584889 b$ & $1238.55 b$ & $1240.96 \mathrm{~b}$ & $40.23 \mathrm{a}$ & $40.16 \mathrm{a}$ \\
\hline Non-weeding & $0.319 \mathrm{~b}$ & $0.300 \mathrm{~b}$ & $0.209 \mathrm{~b}$ & $0.174 \mathrm{~b}$ & $18.30 \mathrm{~b}$ & $16.62 \mathrm{~b}$ & $2.71 \mathrm{~b}$ & $2.70 \mathrm{~b}$ & $1282169 \mathrm{c}$ & $1257741 \mathrm{c}$ & $630.82 \mathrm{c}$ & $618.94 \mathrm{c}$ & $29.71 \mathrm{~b}$ & $30.21 \mathrm{~b}$ \\
\hline
\end{tabular}

Table 7. Comparison of mean of studied cultivars in terms of agronomic traits.

\begin{tabular}{|c|c|c|c|c|c|c|c|c|c|c|c|c|c|c|c|c|}
\hline \multirow{2}{*}{ Cultivar } & \multicolumn{2}{|c|}{ Leaf area } & \multicolumn{2}{|c|}{$\begin{array}{c}\text { Number of lateral } \\
\text { branches }\end{array}$} & \multicolumn{2}{|c|}{ Plant height } & \multicolumn{2}{|c|}{$\begin{array}{l}\text { Distance from first } \\
\text { branch to ground }\end{array}$} & \multicolumn{2}{|c|}{ Stem diameter } & \multicolumn{2}{|c|}{$\begin{array}{l}\text { Number of main } \\
\text { stem pods }\end{array}$} & \multicolumn{2}{|c|}{ Pod length } & \multicolumn{2}{|c|}{$\begin{array}{l}\text { Distance from first } \\
\text { pod to ground }\end{array}$} \\
\hline & $\begin{array}{l}2015- \\
2016\end{array}$ & $\begin{array}{l}2016- \\
2017\end{array}$ & $\begin{array}{l}2015- \\
2016\end{array}$ & $\begin{array}{l}2016- \\
2017\end{array}$ & $\begin{array}{l}2015- \\
2016\end{array}$ & $\begin{array}{l}2016- \\
2017\end{array}$ & $\begin{array}{c}2015- \\
2016\end{array}$ & $\begin{array}{c}2016- \\
2017\end{array}$ & $\begin{array}{l}2015- \\
2016\end{array}$ & $\begin{array}{l}2016- \\
2017\end{array}$ & $\begin{array}{l}2015- \\
2016\end{array}$ & $\begin{array}{c}2016- \\
2017\end{array}$ & $\begin{array}{l}2015- \\
2016\end{array}$ & $\begin{array}{l}2016- \\
2017\end{array}$ & $\begin{array}{l}2015- \\
2016\end{array}$ & $\begin{array}{l}2016- \\
2017\end{array}$ \\
\hline Hayola 401 & $82.48 \mathrm{c}$ & $82.23 c$ & $3.31 \mathrm{a}$ & $3.33 a$ & $135.81 \mathrm{c}$ & $134.62 \mathrm{c}$ & $1.58 \mathrm{~b}$ & $1.41 \mathrm{~b}$ & $53.00 \mathrm{c}$ & $51.18 \mathrm{c}$ & $115.35 \mathrm{a}$ & $113.62 \mathrm{a}$ & $81.24 b$ & $80.25 b$ & $51.43 b$ & $49.81 \mathrm{~b}$ \\
\hline Sarigol & $94.06 \mathrm{a}$ & $93.59 a$ & $1.13 \mathrm{c}$ & $1.00 \mathrm{c}$ & $177.15 \mathrm{a}$ & $176.48 \mathrm{a}$ & $36.78 \mathrm{a}$ & $36.40 \mathrm{a}$ & $70.65 \mathrm{~b}$ & $68.51 \mathrm{~b}$ & $111.94 \mathrm{~b}$ & $109.40 \mathrm{~b}$ & $78.61 \mathrm{c}$ & $77.33 \mathrm{c}$ & $90.11 \mathrm{a}$ & $89.07 \mathrm{a}$ \\
\hline RGS003 & $86.41 \mathrm{~b}$ & $86.30 \mathrm{~b}$ & $3.07 \mathrm{~b}$ & $3.03 \mathrm{~b}$ & $142.81 \mathrm{~b}$ & $141.74 b$ & $1.22 \mathrm{~b}$ & $1.00 \mathrm{~b}$ & $81.35 \mathrm{a}$ & $79.77 \mathrm{a}$ & $103.74 \mathrm{c}$ & $101.96 \mathrm{c}$ & $83.06 \mathrm{a}$ & $82.11 \mathrm{a}$ & $43.41 \mathrm{c}$ & $42.40 \mathrm{c}$ \\
\hline
\end{tabular}

Table 8. Comparison of mean of studied cultivars in terms of agronomic traits.

\begin{tabular}{|c|c|c|c|c|c|c|c|c|c|c|c|c|c|c|}
\hline \multirow[b]{2}{*}{ Cultivar } & \multicolumn{2}{|c|}{ Fresh pod weight } & \multicolumn{2}{|c|}{ Dry pod weight } & \multicolumn{2}{|c|}{ Number of seeds per pod } & \multicolumn{2}{|c|}{ Weight of 1000 seeds } & \multicolumn{2}{|c|}{ Yield per hectare } & \multicolumn{2}{|c|}{ Oil vield } & \multicolumn{2}{|c|}{ Oil percentage } \\
\hline & $\begin{array}{l}2015- \\
2016\end{array}$ & $\begin{array}{l}2016- \\
2017\end{array}$ & $\begin{array}{l}2015- \\
2016\end{array}$ & $\begin{array}{l}2016- \\
2017\end{array}$ & $\begin{array}{l}2015- \\
2016\end{array}$ & $\begin{array}{l}2016- \\
2017\end{array}$ & $\begin{array}{c}2015- \\
2016\end{array}$ & $\begin{array}{l}2016- \\
2017\end{array}$ & $\begin{array}{l}2015- \\
2016\end{array}$ & $\begin{array}{c}2016- \\
2017\end{array}$ & $\begin{array}{l}2015- \\
2016\end{array}$ & $\begin{array}{l}2016- \\
2017\end{array}$ & $\begin{array}{l}2015- \\
2016\end{array}$ & $\begin{array}{l}2016- \\
2017\end{array}$ \\
\hline Hayola 401 & $0.431 \mathrm{a}$ & $0.418 \mathrm{a}$ & $0.263 \mathrm{a}$ & $0.233 \mathrm{a}$ & $21.44 \mathrm{a}$ & $20.00 \mathrm{a}$ & $3.26 \mathrm{a}$ & $3.25 \mathrm{a}$ & $2587407 a$ & $2587333 a$ & $1238.93 \mathrm{a}$ & $1239.35 \mathrm{a}$ & $38.11 \mathrm{a}$ & $38.09 \mathrm{a}$ \\
\hline Sarigol & $0.281 \mathrm{c}$ & $0.262 \mathrm{c}$ & $0.198 \mathrm{~b}$ & $0.155 \mathrm{c}$ & $20.69 a b$ & $19.11 \mathrm{~b}$ & $2.87 \mathrm{~b}$ & $2.89 \mathrm{~b}$ & $2197319 b$ & $2177593 b$ & $1056.19 b$ & $1046.83 b$ & $36.81 \mathrm{~b}$ & $37.08 \mathrm{a}$ \\
\hline RGS003 & $0.317 \mathrm{~b}$ & $0.300 \mathrm{~b}$ & $0.220 \mathrm{~b}$ & $0.181 \mathrm{~b}$ & $20.31 b$ & $19.00 \mathrm{~b}$ & $2.63 \mathrm{c}$ & $2.65 \mathrm{c}$ & $1835943 \mathrm{c}$ & $1813333 \mathrm{c}$ & $884.03 \mathrm{c}$ & $873.2 \mathrm{c}$ & $33.26 \mathrm{c}$ & $33.65 \mathrm{~b}$ \\
\hline
\end{tabular}

Nativa, Sinop, v. 6, n. 3, p. 276-287, mai./jun. 2018 
CLEWIS, S. B.; ASKEW, SH. D.; WILCUT, J. W. Common ragweed interference in peanut. Weed Science, v. 49, p. 68-72, 2001.

DASTPAK, A. Determination of the affinity and chemotaxonomy examination of several cucurbita cultivars. An M.S. thesis, Faculty of Science, Urmia University. 2001.

DHIMA, K.; ELEFTHEROHORINOS, I. Wild mustard (Sinalpis arvensis L.) competition with three winter cereals as affected by nitrogen supply. Journal of Agronomy and Crop Science, v. 191, p. 241-245, 2005.

GHAJARI, A.; GHADERI, F. A. The effect of distance and row of plant density on yield and yield components of cotton cultivars in Gorgan. Iranian Journal of Agriculture Science, v. 12, n. 4, p. 235-239, 2006.

HADIZADEH, M. H.; NOORZADEH, SH.; RAHIMIAN, H. The effect of row spacing and weed free periods on yield and yield components of cotton. Entomology and Phytopathology, v. 69, n. 2, p. 13-26, 2002.

HARPER, J. L. Population biology of plants. Academic Prass. New York1987.
HEJAZI, A. The effect of nitrogen fertilizer and growth stimulant on some qualitative and quantitative traits as well as on autumn rape seed. In: Iranian Congress on Agriculture and Plant Breeding, 1st. Proceedings... Faculty of Agriculture of Karaj. 1992.

JOSHI, N. L.; MALI, P. C.; SEXENA, A. Effect of nitrogen and sulphur application on yield and fatty acid composition of mustard (Brassica juncea L.). Oil. Journal of Agronomy and Crop Science, v. 180, n. 1, p. 59-63, 1998. DOI: https://doi.org/10.1111/j.1439037X.1998.tb00370.x

KHAJEHPOUR, M. R. Industrial plants. Iranian Student Book Agency (ISBA), Isfahan University of Technology, 2004. 564 pages.

KHAN, M. H.; HASSAN, G.; KHAN, N.; KHAN, M. Efficacy of different Herbicides for controlling broadleaf weeds in weat. Asian Journal of Plant Sciences, v. 2, p. 254-256, 1996.

DOI: https://doi.org/10.3923/ajps.2003.254.256

KROPFF, M.; VAN LAAR, H. H. Modeling crop-weed interactions. CAB international. Wallingford. UK. 1993. 